\title{
'WOMAN, BUT NOT HUMAN': WIDOWHOOD PRACTICES AND HUMAN RIGHTS VIOLATIONS IN NIGERIA
}

\author{
EBENEZER DUROJAYE*
}

*Community Law Centre, University of the Western Cape, South Africa

\section{ABSTRACT}

This article examines the implications of widowhood practices for the enjoyment of women's fundamental rights and freedoms in Nigeria. The article discusses the effects of socio-cultural and legal structures of Nigeria for gender equality. It argues that the plural legal system in the country, which encourages the application of statutory law side by side with customary law, can potentially undermine women's fundamental rights. The article then discusses specific human rights of women, particularly the rights to dignity and non-discrimination that are threatened by widowhood practices. In conclusion, it is argued that since Nigeria has ratified international and regional human rights instruments such as the Convention on Elimination of All forms of Discrimination against Women (CEDAW) and the Protocol to the African Charter on the Rights of Women (African Women's Protocol), it is obligated to take appropriate steps and measures to eradicate harmful cultural practices that may violate women's rights.

\section{INTRODUCTION}

Across the world gender inequality remains the norm and women have continued to encounter discriminatory practices as a result of religious and cultural practices. In some parts of the world, particularly Africa, women are still treated like minors and sometimes as second class citizens that are only to be seen and not to be heard (Tamale, 2004; Ssenyenjo 2007). The situation is often compounded in many parts of Africa where patriarchal tradition undermines women's fundamental human rights. Cultural practices such as

The author is grateful to Professor Charles Ngwena of the Centre for Human Rights, University of Pretoria, Professor Akin Oyebode of the University of Lagos and Adeyinka Mojisola for their constant support. This article is dedicated to Ibukunoluwa and Ireoluwa Durojaye.

(C) The Author 2013. Published by Oxford University Press. All rights reserved. For permissions, please email: journals.permissions@oup.com 
female genital mutilation/cutting, widow cleansing, son preference and others are not only demeaning of women but also perpetuate gender inequality. Due to culture and religion, women are assigned different roles in society and are confined to the role of childbearing and homemaking (Mama, 1997; Eboh, 1998). Also, the continued observance of harmful cultural practices has remained threats to women's health and well-being. It is a cause for concern that despite efforts made at the international, regional, and national levels to address gender inequality, women have continued to face discriminatory practices in almost every facet of human endeavour. This in turn can have serious consequences for women's empowerment and development.

Gender relations of power constitute one of the root causes of gender inequality and are among the most influential of the social determinants of health (Cook et al, 2003). Gender inequality may lead to human rights violations, perpetuation of stereotypes, and exclusion of women from political and economic participation. It should be borne in mind that gender inequality not only leads to human rights violations but may also have implications for the overall development of a nation (Mukasa, 2008). Realising the importance of gender equality to socio-economic development, the international community in the Millennium Declaration agreed to eliminate gender inequality in every aspect of human endeavour by $2015 .^{1}$

Ordinarily, widowhood ought to evoke sympathy, empathy, and support from others. However, the situation of widows in Africa is disturbing due to the harrowing experiences they encounter. In addition to the common experience of loss, they have had to put up with other challenges such as deprivation, helplessness, and hopelessness brought about by harmful cultural practices.

Against this backdrop this article examines the implications of widowhood practices for the enjoyment of women's fundamental rights and freedoms in Nigeria. The article discusses the effects of the socio-cultural and legal structures of Nigeria for gender equality. It argues that the plural legal system in the country, which encourages the application of statutory law side by side with customary law, can potentially undermine women's fundamental rights. The article then discusses specific human rights of women, particularly the rights to dignity and non-discrimination that are threatened by widowhood practices. In conclusion, it is argued that since Nigeria has ratified international and regional human rights instruments such as the Convention on Elimination of All forms of Discrimination against Women $(\text { CEDAW })^{2}$ and the Protocol to the African Charter on the Rights of Women (African Women's Protocol), ${ }^{3}$ it is obligated to take appropriate steps and measures to eradicate harmful cultural practices that may violate women's rights. 


\section{SOCIO-CULTURAL AND LEGAL CONTEXT OF THE NIGERIAN SOCIETY}

Nigeria is the most populous country in Africa with diverse people and cultures. The over 150 million population comprises about 200 ethnic groups with different dialects (NPC, 2006). The country is known to be highly religious and majority of its population are either Christians or Muslims, while others practice African traditional religion. A significant number of the Christians live in the southern part of the country, while a large number of Muslims are found in the northern parts of the country. The two major religions in the country lay emphasis on the need for a wife to submit totally to her husband in every aspect of life, including sexual intercourse.

From 1960, when the country obtained its independence from Britain until 1999, the greater part of the country's political history has been under different military regimes. During military rule, the constitutional provisions on fundamental rights were suspended and replaced by autocratic decrees. The military era was characterised by centralisation of powers, flagrant violations of human rights, particularly of marginalised and disadvantaged groups such as women and children. Moreover, military dictatorship was synonymous with endemic corruption and mismanagement and exhibited lack of political will to address gender inequality. While the return to democratic rule in 1999 has elicited much excitement and hope for a promising future, the position of women in the country has not in any way changed from what it was during military rule. Women's participation in politics remains skewed in comparison to men as they are poorly represented in the legislative and executive arms of government and continue to experience discriminatory practices on a daily basis. ${ }^{4}$

As a former colony of Britain, Nigeria adopts the common law legal system, which places emphasis on judicial precedent. However, in practice the country derives its sources of law from legislation, customary laws, and Shari'ah. Although Islamic law and indigenous customary laws preceded the common law system, the latter by virtue of colonialism has tended to take pre-eminence over the former. The application of these three systems side by side in a diverse country with different ethnic and religious groupings has implications for women's rights. It should be noted that Nigeria is a federation and as such each component state has powers to make laws. While some statutory provisions such as the Constitution tend to give recognition to women's rights, customary laws and Shari'ah tend to perpetuate gender inequality. For instance, while Section 42 of the Constitution guarantees all individuals equal rights and freedoms and proscribes discrimination on grounds of sex, some cultural practices such as wife inheritance or primogeniture system $^{5}$ seem to be inconsistent with this provision. In summing up 
how cultural practices perpetuate the subordinate position of women, Williams (2004) opines that the Nigerian woman is defined in terms of her role as a mother and a wife and that her worth depends on her marital status since her legal and social status are tied to her husband's.

Furthermore, some provisions of Shari'ah as applicable in most parts of the northern region of the country perpetuate the low status of women. For instance, while Sections 21 and 22 of the Child's Rights Act of 2003 prohibit early marriage by setting the marriageable age at 18, Islamic law (Shari'ah) permits early marriage and prohibits adolescent girls from seeking contraceptive services. Child or early marriage is prevalent in the northern parts of Nigeria where girls are often married at 12 years or younger. ${ }^{6}$ When a girl is married at an early age, she is deprived the opportunity to be educated and developed mentally and physically and to earn a means of livelihood. This clearly underlines the tension that may exist between statutory law and customary or religious law in a multi-cultural society like Nigeria.

The plural legal nature of Nigeria potentially creates an avenue for confusion and uncertainty regarding the promotion and protection of women's fundamental rights and freedoms. Bond (2010) has argued that legal pluralism can potentially undermine women's rights to exercise free choices in matters that affect their sexual and reproductive well-being. Also, in explaining the effects of legal pluralism for women's rights in Nigeria, Ewelukwa (2002) has noted as follows:

Fundamental contradictions inherent in the legal system - the coexistence of modern, statutory laws with traditional customary laws and practices - has created a complex and confusing legal regime under which women generally are denied adequate legal protection ... Not surprisingly, many of the problems which are faced today in much of Africa 'are the product of trying to piece together, in a hasty fashion, not only the different legal systems but also fundamentally different conceptions of society and the family.

Iwobi (2008) has echoed this position when he observed that legal pluralism can potentially lead to the adoption of laws and practices that may be inimical to the rights of women.

WIDOWHOOD PRACTICES IN HISTORICAL PERSPECTIVE

Widowhood practices or burial rites are by no means peculiar to Nigeria as they are commonly practised across Africa. In different parts of Africa, various forms of rites are performed when a woman losses her husband. In many parts of Africa, a bereaved spouse is expected to undergo certain rites upon becoming a widow or widower. In some situations, the nature and forms of these rites vary depending on culture and beliefs. Widowhood rites, often by-products of 
institutionalised socio-cultural norms, are more or less social obligations for women. It is also a period when a widow is expected to grieve and mourn the loss of a beloved one, particularly a husband (Samuel, 2011: 185). Irrespective of whether a marriage results in children or not, widowhood practices are observed, particularly for a woman married under customary law.

Widowhood or burial rites are performed not only to mourn the dead but also to ensure that the link between the dead and the living is intact. Thus, the period of mourning is often accompanied by series of life events and activities to show respect for the soul of the departed spouse. ${ }^{7}$ These practices range from widow cleansing in Eastern parts of Africa, levirate marriage in Southern Africa, to shaving of the widow's hair or other degrading treatments (Amstrong et al, 1993). Whatever form they may take widowhood practices tend to include various forms of inhuman, demeaning, and barbaric acts that may endanger the life of a woman. Some commentators have argued that widowhood practices are not only tools to perpetuate gender inequality but are also barbaric, atrocious, unethical, and a gross violation of women's fundamental rights and freedom (Sossou, 2002; Nyanzi et al, 2009: 13).

In her award winning novel So Long a Letter, Ba (1981) vividly captures the oppressive nature of culture in a patriarchal environment. More importantly, the novel mirrors the sorrow, suffering, and humiliation widows often experience as a result of burial rites in a patriarchal African setting. The experience of Ramatoulaye (the protagonist of the novel) after the death of her husband in the novel is that of a woman suffocating under the whims of culture. Rather than receiving comfort or succour from her late husband's family, she is faced with a cultural practice, which requires that she be married to her late husband's brother or be thrown out of her home. This novel underscores the difficult choices a woman is forced to make upon the death of her husband in a typically patriarchal African society.

Interestingly, these burial rites are often performed when a woman losses her husband and not the other way round. This tends to raise concerns about the discriminatory nature and rationale for these practices. Generally, widowhood practices are observed to various degrees among different cultural and ethnic groups in Nigeria. ${ }^{8}$ The duration of the mourning period and the nature of activities to be performed may differ from one ethnic group to another. For instance, among a community in Delta area of Nigeria, 'after an initial seven-day confinement, a subsequent thirty-day confinement for mourning in a tiny outdoor hut is mandatory for widows' (Ewelukwa, 2002). This period is accompanied by isolation and shaving of the hair. Whereas among the Yorubas of the south-west, the duration of the burial rites, which may include wearing of dark clothes, weaving or cutting of hair, 
refraining from taking bath and wailing, ranges from 7 days to a year (Oyeniyi and Ayodeji, 2010).

Among the Igbos of the south-eastern part of Nigeria, a widow is subjected to various degrees of dehumanising practices or rites all in the name of customs and traditions. These may include denial of inheritance rights, shaving of hair, drinking from the water used in bathing the deceased spouse to sitting and sleeping on the floor. In a popular documentary titled 'Till Death do us part' by a nongovernmental organisation Communication for Change 1999, ${ }^{9}$ three women who had undergone the humiliation and suffering associated with widowhood practices in the Eastern part of Nigeria recounted their experiences. One of the women, Nnameka Ezeonu, lamented that she was not allowed to eat or drink until her husband was buried. The women further recounted how they were forced to drink the water used to bathe their dead husbands and how they slept in the same room with their husbands' corpses during this mourning period. In some parts of Igbo culture a widow is expected to wear black clothes during the period of mourning.

In some situations, a widow is expected to compel her married daughter to shave her head and pubic area. Worse still, a widow may be dispossessed of the property left behind by her late husband. One of the women in the documentary referred to above, recounted that she was living in a two-bedroom flat and had a car before the death of her husband, but was dispossessed of all these shortly after her husband died. This is an indication that widowhood practices may not only perpetuate gender inequality but may also deny women access to economic resources and lead to poverty. It has been noted that 'forced eviction may arise where a woman has been compelled to leave her home due to actual or presumed acts of violence or discriminatory customary laws that deny women rights of inheritance' (COHRE, 2002).

\section{JUSTIFYING WIDOWHOOD PRACTICES}

It is believed that these practices are observed in order to determine the innocence of a woman with regard to the death of her husband. The belief is that a man could not have died of a natural cause. Therefore, it is necessary to ascertain the cause of his death (Oyeniyi and Ayodeji, 2010). Unfortunately, the wife of a deceased is often the prime suspect in this situation and will have to undergo these excruciating practices to prove her innocence.

Proponents of widowhood practices have contended that these burial rites are necessary in order to ward off the evil spirits of the deceased from intruding. They have also argued that long confinement and 
isolation are necessary in order to mortify the body of the widow and test her endurance in time of mourning. Moreover, they contend that these practices should not be viewed as a violation of women's rights but as fulfilling cultural expectations of the people.

These arguments tend to bring to the fore once more the tension that often exists between culture and human rights. Cultural relativists have argued that it is erroneous to use Western notion of human rights as universal standards for all individuals regardless of their jurisdiction and beliefs. According to cultural relativists, since human rights principles and standards originate from the West, it is misleading to ascribe 'universalism' to human rights guarantees as they do not necessarily reflect the cultures of developing countries, particularly African countries. Obiora (1996-1997) has cautioned about the often touted universalistic norms and standards of human rights as this may be nothing more than Western imposition. Cobbah (1987) similarly argues that the emphasis placed on individualism by human rights principles is inconsistent with African lifestyle, which is based on 'communalism and togetherness'. He argues further that the idea of individualism is more or less an abstraction, which tends to alienate an individual from the 'harmonious, congruous, and holistic totality known to the medieval society'. Other commentators have argued that scholars from the West are often quick at criticising and condemning cultural practices of other people without a careful reflection on the origin and relevance of those practices (Gunning, 1992; Lewis, 1995). Tamale (2008) has noted that there are positive and negative aspects of every culture and that it is misleading to assume that all African cultures interfere with the enjoyment of women's rights.

However, critics of cultural relativism argue that cultures are never static but change with time. Thus, it is of no value to retain obsolete and potentially harmful cultural practices, which may interfere with enjoyment of individuals' rights. For instance Terry (2007) argues that cultural relativism fails to recognise power imbalances and relations that exist in most societies and how these limit women's choices and rights. Furthermore, she submits that if cultural relativism is taken to its logical conclusion, then it will mean that one should accept any behaviour no matter how crude or inhuman. Donnelly (1984), one of the leading proponents of Universalism, has summarised the contemporary doctrine of Universalism in the following way.

(i) All humans have rights by virtue of their humanity;

(ii) A person's right cannot be conditioned by gender or national or ethnic origin;

(iii) Human rights exist universally as the highest moral rights, so no right can be subordinated to another person, or to an institution. 
It has been argued that the inherent dignity of human persons is not a matter for state consent, but a sacred predicate for an international moral order that transcends the boundaries of cultural and religious diversity (Obiora, 1996-1997).

\section{HUMAN RIGHTS IMPLICATIONS OF WIDOWHOOD PRACTICES}

From the foregoing discussion it is clear that widowhood practices have implications for women's fundamental rights and freedom. In particular, these practices may likely infringe women's rights to dignity, non-discrimination and equality, health, and life. However, the focus here will be on two major rights, dignity and non-discrimination, that are more likely to be directly affected by widowhood practices. As noted earlier, Nigeria has ratified major international and regional human rights instruments protecting women's rights. In addition, the 1999 Constitution contains provisions that can be invoked to protect women's rights in the context of harmful cultural practices. Under international human rights law states are obligated to respect, protect and fulfil all human rights, including the rights of women. The discussion in this section focuses on the human rights implications of widowhood practices and the obligations of the Nigerian government to address the situation.

\section{THE RIGHT TO DIGNITY}

One of the most important rights widowhood practices may infringe is the right of women to dignity. The right to dignity is one of the most fundamental rights enjoyed by all individuals. It is well recognised in almost all the international and regional human rights instruments. The preamble of the Universal Declaration on Human Rights (UDHR) declares that the recognition of dignity and of the equal and inalienable rights of all individuals is the foundation of freedom, justice, and peace in the world. ${ }^{10}$ Article 1 of the UDHR further states that 'All human beings are born free and equal in dignity and rights. They are endowed with reason and conscience and should act towards one another in a spirit of brotherhood'.

In other human rights instruments, the protection of human dignity is often expressed in provisions relating to the right to be free from inhuman and degrading treatment. For example, Article 7 of the International Covenant on Civil and Political Rights (ICCPR) provides that 'No one shall be subjected to torture or cruel and inhuman or degrading treatment or punishment. In particular no one shall be subjected without his free consent to medical or scientific experimentation'. ${ }^{11}$ This provision has often been interpreted to ensure that 
prisoners are treated in humane ways. However, recent developments have shown that national courts and human rights tribunals now tend to interpret this provision in such a way so as to ensure that the dignity of women and girls is respected. For example, the Indian Supreme Court in the case of Vishaka $v$ State of Rajasthan, ${ }^{12}$ has explained that sexual harassment of a woman violates the constitutional guarantees of a woman's rights to life and dignity. In that case, a woman was gang raped by five men from the local community because she attempted to stop the marriage of a one-year-old baby. Relying on the Constitution's Directive Principles, the Court noted that the Indian government has the duty to secure just and humane conditions and to renounce practices derogatory to the dignity of women. Therefore, it concludes that in this instance, the government has breached its obligations under international law to protect women from violence.

This decision by the Indian Supreme Court is a welcome development and would seem to coincide with the reasoning of the Committee on CEDAW in its General Recommendation $19^{13}$ on violence against women. The Committee had noted that a state may be held responsible for private acts of violence against women if the state fails to take necessary measures to prevent such violence. As explained above, widowhood practices are sometimes accompanied by act of violence such as forceful eviction of a woman from her property. These constitute threats to a woman's dignity.

Under the African Charter, Article 5 recognises an individual's right to dignity. It provides that 'Every individual shall have the right to the respect of the dignity inherent in a human to the recognition of his legal status'. It further prohibits all forms of cruel, inhuman, and degrading treatment against any human being. Also, Article 3 of the African Women's Protocol guarantees women's rights to human dignity. It provides that 'Every woman shall have the right to dignity inherent in a human being and to the recognition and protection of her human and legal rights'. Article 3 further provides that 'Every woman shall have the right to respect as a person and to the free development of her personality'.

The African Commission on Human and People's Rights (African Commission) in Curtis Francis Doebbler $v$ Sudan ${ }^{14}$ has given a broad interpretation to the legal obligations imposed by Article 5 of the African Charter on states. In that case, eight Muslim university students on a picnic were arrested and charged with committing, in a public place, acts contrary to public morality, prohibited under Article 153 of the Sudanese Criminal Law of $1991 .{ }^{15}$ The provision of that law prohibits acts such as girls kissing, wearing trousers, dancing with men, crossing legs with men, and sitting and talking with boys. The girls were subsequently convicted and sentenced to fines and lashes, which would be carried out in public under the supervision of the national court. The 
complainants alleged that the punishment violated Article 5 of the African Charter. In agreeing with the complainants the Commission noted as follows:

Article 5 of the Charter prohibits not only cruel but also inhuman and degrading treatment. This includes not only actions which cause serious physical or psychological suffering, but which also humiliate or force the individual [to act] against his will or conscience. ${ }^{16}$

This broad interpretation by the Commission would implicitly render widowhood practices as cruel, inhuman, and degrading treatment against women. The fact that some of the widows are forced to eat and sleep on the floor, attests to the dehumanising nature of these practices. It is also not in contention that widowhood practices cause physical and psychological sufferings to women. Article 20(1) (a) of the African Women's Protocol specifically enjoins African governments to take appropriate measures in order to ensure that women are not subjected to inhuman, humiliating, and degrading treatment. It should be noted that Section 34 of the Nigerian Constitution provides that 'Every individual is entitled to respect for the dignity of his person'. It states further in paragraph (a) of subsection 1 that no person shall be subjected to torture or to inhuman or degrading treatment. Given this provision of the Constitution and the fact that Nigeria has ratified most of the human rights instruments mentioned above, the government is under obligation to ensure that women are protected from being subjected to acts of degrading and inhuman treatment.

During the Vienna Conference on human rights it was noted that sexual harassment and exploitation of women, including those arising from cultural prejudice, are incompatible with the dignity and worth of human person and must be eliminated. ${ }^{17}$ This sentiment was echoed at both the International Conference on Population and Development and the Fourth World Conference on Women. At these conferences, the international community noted that low socio-economic status of women, acts of discrimination and their exposure to violence will impact negatively on their rights and well-being. ${ }^{18}$

In one of its Concluding Observations to the government of Nigeria, the CEDAW Committee (2008) has expressed grave concern as regards 'the persistence of entrenched harmful and cultural norms and practices, including widowhood rites and practices' and its implications for women's rights. ${ }^{19}$ It therefore, urges the government of Nigeria, as a matter of priority to take decisive steps in order to address this situation. ${ }^{20}$ These observations are consistent with ensuring the dignity of women and obligating the Nigerian government to ensure that women are protected from dehumanising and degrading practices perpetrated by third parties, particularly in the context of widowhood practices. 
Every human being by reason of being human is entitled to be treated with dignity, or with a minimum of respect and decency. Margalit (2003) has noted that dignity unlike honour, is not a positional good, rather it should be accorded to everybody, by virtue of the most universal common denominator of being human. Also, Donnelly (2003) has argued that 'We have human rights not to the requisites for health but to those things "needed" for a life of dignity, for a life worthy of a human being, a life that cannot be enjoyed without these rights'.

Considering the importance of the right to dignity to the enjoyment of other human rights this right has been described to be a "mother right' in two senses. Firstly, the majority of fundamental rights can be derived from it. Secondly, a series of rights not emphasised in a constitution can be drawn from it. ${ }^{21}$ While reiterating this point, Justice O'Regan of the South African Constitutional Court in $S v$ Makwanyane noted as follows:

The importance of dignity as the founding value of the new Constitution cannot be overemphasized. Recognizing the right to dignity is an acknowledgment of an intrinsic worth of human beings: human beings are to be treated as worthy of respect and concern. ${ }^{22}$

The horrifying and degrading experience women often undergo as a result of widowhood practices in many parts of Nigeria will no doubt constitute a violation of their right to dignity. These practices are demeaning of women and erode their intrinsic worth as human beings. The Nigerian Court in Nice v Attorney General of the Federation ${ }^{23}$ has explained that dragging an accused person on the floor and forcing another man to lie on him constitute inhuman and degrading treatment. In sum, the broad interpretation of these decisions is that widowhood practices impinge a woman's dignity.

\section{THE RIGHT TO EQUALITY AND NON-DISGRIMINATION}

One of the concerns raised regarding widowhood practices is that they tend to perpetuate gender inequality and the low status of women in society. The principles of equality and non-discrimination are well-recognised in virtually all human rights instruments. Article 2 of the International Covenant on Civil and Political Rights provides that all the rights guaranteed in the Covenant must be enjoyed by all without distinction or discrimination. According to Article 1 of CEDAW, discrimination against women is defined to mean

'[A]ny distinction, exclusion or restriction made on the basis of sex which has the effect or purpose of impairing or nullifying the recognition, enjoyment or exercise by women, irrespective of their marital status, on a basis of equality of men and women, of human rights and fundamental freedoms in the political, economic, social, cultural, civil or any other field. ${ }^{24}$ 
This is a broad definition and would seem to coincide with the notion of substantive equality. Article 2 of CEDAW further urges states parties to take necessary steps and measures with a view to eliminating discriminatory practices against women. In addition, Article 16 of CEDAW enjoins states parties to take all necessary measures to eliminate discrimination against women in all matters relating to marriage and family relations. This is one of the provisions of CEDAW with high number of reservations by states parties. ${ }^{25}$ However, Nigeria has not entered any reservation to the provisions of CEDAW.

Borrowing the language of CEDAW, the African Women's Protocol defines discrimination to include: ${ }^{26}$

[Any] distinction, exclusion or restriction or any differential treatment based on sex and whose objectives or effects compromise or destroy the recognition, enjoyment or the exercise by women, regardless of their mental status, of human rights and fundamental freedoms in all spheres of life

The Protocol further requires states to remove practices that discriminate against women and urges states parties to take all appropriate steps to eliminate social and cultural patterns and practices that are discriminatory to women. ${ }^{27}$ Specifically, Article 2(2) provides thus:

'States Parties shall commit themselves to modify the social and cultural patterns of conduct of women and men through public information, education and communication strategies, with a view to achieving the elimination of harmful cultural and traditional practices and all other practices which are based on the idea of the inferiority or the superiority of either of the sexes, or on stereotyped roles for women and men.

In a bid to address the negative impact of widowhood practices on women, Article 21 of the African Women's Protocol provides that widows shall have the right to an equitable share in the inheritance of the property of their husbands. A widow shall have the right to continue to live in the matrimonial house. In case of remarriage, she shall 'retain this right if the house belongs to her or if she has inherited it'. This provision is intended to protect African women from cultural practices that deny them of rights to inheritance. Chirwa (2006) has noted that this provision is significant in the sense that it aims at correcting past injustices and suffering African women have experienced with regard to inheriting from either their deceased parents or husbands. It is instructive to note here that the African Women's Protocol adopts the use of the phrase 'equitable share' instead of 'equal share'. Banda (2006) has rightly questioned this approach of the Protocol. Given the difference between the two phrases and in light of the substantive equality stance of the Protocol, one would have expected the drafters of the Protocol to 
adopt a clearer language capable of protecting women's rights. Equity means fairness, therefore, 'equitable share' would imply 'fair share' and does not necessarily mean the same as equal share. The CEDAW Committee has noted that the terms 'equity' and 'equality' are not the same and should not be used interchangeably. ${ }^{28}$ In addition, the Committee explains that the main aim of the Convention is to eliminate discrimination between men and women and ensure de jure and de facto equality between men and women. More importantly, the Committee enjoins states to use the word 'equality' rather than 'equity'. ${ }^{29}$

The Human Rights Committee in its General Comment 18 has explained that equality together with non-discrimination constitutes a basic and general principle relating to the protection of human rights. ${ }^{30}$ Also, in its General Comment 28, the Committee explains that all individuals are expected to enjoy the rights guaranteed in the ICCPR on an equal basis and in totality and that a state is in breach of the principle of equality whenever any person is denied the full and equal enjoyment of all rights. ${ }^{31}$ More specifically, in relation to cultural practices the Committee notes as follows:

'Inequality in the enjoyment of rights by women throughout the world is deeply embedded in tradition, history and culture, including religious attitudes. ... States parties should ensure that traditional, historical, religious or cultural attitudes are not used to justify violations of women's right to equality before the law and to equal enjoyment of all Covenant [ICCPR] rights' ${ }^{32}$.

Thus, the Committee urges states to ensure equal enjoyment of all rights for men and women. As discussed above, widowhood practices prevent women from enjoying some of their basic rights and freedoms. Therefore, they will constitute unfair discrimination to women. The mere fact that women are the target of these practices further reinforces their discriminatory nature.

The African Commission on Human and People's Rights in Legal Resources Centre $v$ Zambia $^{33}$ has explained the importance of Articles 2 and 3 of the Charter dealing with non-discrimination and equal rights. According to the Commission, the right to equality is very important in that it means that citizens should expect to be treated fairly and justly within the legal system and be assured of equal treatment before the law and equal enjoyment of all rights available to other citizens. The Commission notes further that the right to equality is very important for a second reason because 'equality or lack of it affects the capacity of one to enjoy many other rights'.

The preamble to the Nigerian Constitution envisages a country where government pays attention to the need of the people based on the principles of freedom, equality, and justice, and for the purpose of 
consolidating the unity of the people. In addition, Section 42 of the Constitution provides as follows:

A citizen of Nigeria of a particular community, ethnic group, place of origin, sex, religion or political opinion shall not, by reason only that he is such a person:-

(a) be subjected either expressly by, or in the practical application of, any law in force in Nigeria or any executive or administrative action of the government, to disabilities or restrictions to which citizens of Nigeria of other communities, ethnic groups, places of origin, sex, religious or political opinions are not made subject'

The import of this provision is that discriminatory practices against individuals based on the prohibited grounds are forbidden. Although the Nigerian Constitution, unlike Section 9 of the South African Constitution, does not use the word 'gender' it can be argued that the use of the word 'sex' would protect women from discriminatory practices. This would seem to suggest that denial of political and economic opportunities to women together with the observance of harmful cultural practices would be inconsistent with the provision of Section 42 of the Constitution. It should be noted that Section 42 of the Constitution must be read together with Section 1. Section 1(3) declares that the Constitution is supreme and that any law that is inconsistent with it will be null and void according to its inconsistency. The implication of this is that the continued adoption of cultural or religious practices, which may discriminate against women, will be in violation of the provision of the Constitution.

Nigerian courts are yet to develop a consistent jurisprudence clarifying the content and meaning of the equality provision in Section 42. Moreover, an opportunity for the Supreme Court to clarify the meaning of this section, particularly in relation to widowhood practices, was missed in the Mojekwu case. ${ }^{34}$ The Supreme Court adopted a narrow interpretation of this provision and failed to apply it to reflect women's lived experiences. In that case, the court was asked to determine the lawfulness or otherwise of a customary practice among Onitsha people of south-eastern Nigeria, which prevents a female child from inheriting from her deceased father. While the Supreme Court upheld the Court of Appeal's decision in Mojekwu $v$ Mojekwu ${ }^{35}$ to the extent that the respondent widow and her family were entitled to the disputed property, the Court berated the Court of Appeal for applying the repugnancy test doctrine to the $\mathrm{O} l i$-Ekpe custom ${ }^{36}$ and for declaring it to be inconsistent with international human rights instruments. The fact that the Supreme Court was reluctant to hold the cultural practice among the Igbo people of Eastern Nigeria, which denies a female child the right to inherit from her deceased father as discriminating and in violation of Section 42, clearly shows the mindset of the Supreme Court judges. The 
conservative and insensitive approach of the court is more or less a betrayal of the spirit of the Constitution and more particularly Section 42 (Ewelukwa, 2002; Iwobi, 2008).

However, in a more recent case, the Court of Appeal in Asika and others $v$ Atunay $a^{37}$ while addressing a similar customary practice has held as follows:

It seems that these provisions especially the provision as contained in Section 42 (2) of the Constitution indeed is so specific and categorical that "No citizen of Nigeria shall be subjected to any disability or deprivation merely by reason of the circumstances of his birth." .. Again one may ask why in some parts of Nigeria women are by subordinate laws and customs deprived of ownership and right of inheritance to acquire and own immovable property. Why are the women subjected to this disability or deprivation by reason only of their feminine attribute? The constitutional provisions are quite clear and unambiguous. Despite the lack of ambiguity in the constitution, Nigeria women in certain parts of Nigeria are not entitled to inherit any landed property as was envisaged in this appeal,

This approach is better in that it is progressive and more sensitive to the situations of women in the country. It speaks to the needs of women and clearly addresses the human rights violations, which may occur as a result of adherence to harmful cultural practices. It remains unclear how influential this decision will be given that it emanated from the Court of Appeal rather than the Supreme Court - the highest court in Nigeria. Given the importance of access to land as a means of liberating women from poverty, the position of the Supreme Court in the Mojekwu case can undermine women's opportunity to lead a worthy and dignified life. This decision can be contrasted with the South African Constitutional Court decision in the Bhe $\mathcal{E}$ Others $v$ Magistrate Khayelitsha [2005 (1) BCLR 1 (CC)] case in relation to a similar primogeniture customary practice. In condemning the primogeniture customary practice, the Court noted as follows:

The exclusion of women from inheritance on the grounds of gender is a clear violation of section 9 (3) of the Constitution... The principle of primogeniture also violates the right of women to human dignity as guaranteed in section 10 of the Constitution as, in one sense, it implies that women are not fit or competent to own and administer property.

The approach of the South African Constitutional Court in the Bhe case is not only progressive but also capable of advancing women's fundamental rights to equality and dignity. It would seem to have taken into consideration the lived experiences of women. There is need for a coherent and consistent approach by Nigerian courts in interpreting Section 42 of the Constitution vis-à-vis customary practices. Given that the provision of Section 42 is clear and unambiguous, a more nuanced approach that strikes a balance between culture and women's 
fundamental rights is required. While it is noted that not all cultural practices are bad or harmful, the court should not hesitate to strike down those cultural practices that are dehumanising and interfere with women's enjoyment of their fundamental rights and freedoms.

It should be noted that there is no specific law at the national level addressing gender inequality in the country. An attempt made at domesticating the provisions of CEDAW through the "Abolition of all forms of Discrimination Against Women in Nigeria and Other Related Matters Bill, 2006' (CEDAW Bill), was frustrated by the legislature. However, some states such as Edo, Enugu, Ekiti, Ebonyi, and Anambra, have all enacted laws that specifically deal with harmful cultural practices including female genital mutilation and wildwood practices. ${ }^{38}$ In addition, Nigeria has adopted a number of policy measures, including the adoption of National Gender Policy of 2006 in response to the prevailing gender inequality in the country. The Policy aims at complementing the provision of Section 42 of the 1999 Constitution of Nigeria, which prohibits discrimination on different grounds including sex. Its main goal is to 'build a just society devoid of discrimination, harness the full potentials of all social groups regardless of sex or circumstance, promote the enjoyment of fundamental human rights and protect the health, social, economic and political well-being of all citizens in order to achieve equitable rapid economic growth' (Federal Ministry of Women, 2006).

Sadly, however, studies have shown that cultural practices and stereotypes have continued to perpetuate discrimination against women and the political will to implement laws and policies addressing gender inequality is weak. For instance, a study in six geo-political zones of the country by the AAWORD ${ }^{39}$ reveals trends in level of gender inequality and discrimination against women. More importantly, the study reveals that challenges still exist with regard to changing perceptions about deep cultural or traditional beliefs and practices that are inimical to women's health and well-being. Many of the respondents in this study hold the view that men are superior to women and that they are the breadwinners for the family. Women are generally viewed as inferior, weak, and incapable of assuming a position of authority. Also, about $65 \%$ of the respondents believe that men are the main decision-makers in the family. The significance of these findings is that gender inequality remains a great challenge as women are still regarded as inferior to men in almost every aspect of human endeavour.

The CEDAW Committee on a number of occasions has called on states to take necessary measures with a view to eliminating cultural practices and stereotypes that continue to perpetuate discrimination against women. ${ }^{40}$ For instance, in its General Recommendation 21 on marriage and family relations, the Committee has expressed concerns with regard to how laws and practices on inheritance continue to 
discriminate against women. According to the Committee, such practices tend to disadvantage women and undermine the principle of equality. ${ }^{41}$ Therefore, the Committee enjoins states parties to adopt a wide range of strategies including education and awareness campaign at local level to address this situation. Also, in General Recommendation 27 on older women the Committee urges states parties to repeal discriminatory inheritance laws against older women and instead adopt inheritance laws that are consistent with their obligations under the Convention. ${ }^{42}$ The Committee has explained in its General Recommendation 28 that Article 2 of the Convention imposes obligations on states to ensure that the principles of equality and nondiscrimination are enshrined in domestic laws. ${ }^{43}$

In one of its Concluding Observations to the government of Nigeria, the Committee has expressed grave concern regarding the impact of harmful cultural practices for the realisation of women's rights. ${ }^{44}$ The Committee thus called on the government of Nigeria to reform its law and policies with a view to ensuring equal enjoyment of fundamental rights for all. In one of its reports to the Committee on the Convention on the Rights of the Child (CRC), the Nigerian government observed that one of the greatest setbacks to its efforts in promoting gender equality in the country includes deep-rooted cultural, traditional, and religious practices that continue to discriminate against the girl-child. ${ }^{45}$ In response to this report, the Committee on the CRC in its Concluding Observations to the government of Nigeria noted that the girl-child has continued to suffer discrimination due to cultural and religious practices in the country. ${ }^{46}$ In particular, the Committee has noted that the girl-child has continued to be excluded from inheriting property from her deceased father. The Committee further noted that this practice is in violation of international human rights law, which prohibits discrimination on various grounds including sex and gender. ${ }^{47}$ The Committee then enjoined the Nigerian government to take a more proactive approach to addressing this situation.

It should be noted that under international law a state has both negative and positive obligations with regard to addressing discrimination in the context of gender. The negative obligation implies that a state must refrain from discrimination either by its laws or actions. In its General Comment 18 the Human Rights Committee has explained that Article 26 of the ICCPR obligates states to ensure that its laws and implementation thereof do not discriminate on any of the prohibited grounds. ${ }^{48}$ On the other hand, the positive obligation would require that states take concrete measures to eliminate discrimination. This will require the implementation of anti-discrimination law or the adoption of policies or strategies to eliminate gender discrimination. For instance, it will be expected that the Nigerian government will adopt laws and policies 
to combat the negative implications of widowhood practices in the country.

\section{CONCLUSION}

This article has shown that despite efforts made at the international level to address gender inequality, women still encounter discriminatory practices on a daily basis. In particular, cultural practices such as widowhood practices have continued to perpetuate the subordinate position of Nigerian women. Moreover, widowhood practices are a violation of women's rights to dignity and non-discrimination guaranteed in the Nigerian Constitution. Given that Nigeria has ratified international and regional human rights instruments that prohibit discrimination against women, it is imperative that the government adopts appropriate steps and measures to address cultural practices that continue to discriminate against women.

The Nigerian government will need to embark on holistic legal and social reforms that must respond to the peculiar needs of women in the country. The government would need to immediately abolish cultural practices that continue to perpetuate inferior status of women in society. Moreover, the government will need to enact laws that will promote gender equality in society and protect women from discriminatory practices in general. Such efforts will need to be complemented by education and awareness campaign programmes targeted at correcting stereotypical attitudes towards women.

\section{NOTES}

\footnotetext{
${ }^{1}$ UN Millennium Declaration and Millennium Development Goals launched in 2000.

${ }^{2}$ Convention on the Elimination of All Forms of Discrimination Against Women GA Res 54/180 UN GAOR 34th Session Supp No 46 UN Doc A/34/46 1980.

3 The Protocol of African Charter on Human and People's Rights on the Rights of Women in Africa Adopted by the 2nd Ordinary Session of the African Union General Assembly in 2003 in Maputo CAB/LEG/66.6 (2003) entered into force 25 November 2005.

${ }^{4}$ See Nigeria CEDAW NGO Coalition Shadow Report: Submitted to the 41 st Session of the UN Committee on CEDAW (2008).

${ }^{5}$ A cultural practice common among the Igbo of the Eastern part of the country, which tends to deny a female child right of inheritance.

${ }^{6}$ UNICEF 'Early Marriage: Sub-Saharan Africa Indicted for Child Marriages' available at http:// www.rozanehmagazine.com/julyaugust02/Mayjune02new/womanunicef.html (accessed 8 May 2012).

${ }^{7}$ Communication for Change 'Till Death do us part' available at http://cfcnigeria.org/content/tilldeath.htm\#video (accessed 8 May 2012).

${ }^{8}$ O Olakitike 'Cruelty in the name of Culture' (2009) Pulsewire Magazine http://www.worldpulse.com/user/1265/journal. (accessed 6 August 2012).

${ }^{9}$ See note 7 above.

${ }^{10}$ Universal Declaration on Human Rights (UDHR) adopted on 10 December 1948. GA res.217A(III) U.N Doc A.
} 
${ }^{11}$ International Covenant on Civil and Political Rights, G.A. Res. 2200, U.N. GAOR, Supp. No. 16 at 52, U.N. DOC. A/6316 (1966), 999 U.N.T.S. 171, 174 (entered into force on 23 March 1976) (herein after ICCPR).

12 (1997) 6 SCC241 (Indian Supreme Court).

${ }^{13}$ CEDAW, General Recommendation 19 on Violence Against Women, UN GAOR, 1992, Doc. No. A/47/38.

${ }^{14}$ Communication 236/2000, Curtis Francis Doebbler v. Sudan, Sixteenth Annual Activity Report of the African Commission on Human and Peoples' Rights (Annex VII); see also, Baderin, M. (2005) 'Recent developments in the African regional human rights system', Human Rights Law Review 5, 133.

${ }^{15}$ Article 152 of the Sudanese Criminal Law of 1991 provides as follows:

'1. Whoever commits, in a public place, an act, or conducts himself in an indecent or immoral dress, which causes annoyance to public feelings, shall be punished, with whipping, not exceeding forty lashes, or with fine, or with both. 2. The act shall be deemed contrary to public morality, if it is so considered in the religion of the doer, or the custom'.

${ }^{16}$ Curtis Francis Doebbler v. Sudan above note 12 para 36.

${ }^{17}$ Vienna Programme of Action UN Doc A/CONF 157/24 Part 1 ch III para 18.

${ }^{18}$ See for instance, Report of the International Conference on Population and Development (ICPD) 7, UN Doc A/CONF.171/13 (1994) para 4.1; see also Fourth World Conference on Women (FWCW) Beijing held on 15 September 1995 A/CONF.177/20 para 92.

${ }^{19}$ Concluding Observations of the Committee on CEDAW: Nigeria 41st Session 30 June-18 July 2008 CEDAW/C.NGA/CO/ 6.

${ }^{20}$ Ibid., paras 336-337.

${ }^{21}$ Pazczolay, The Prohibition of Discrimination by the Constitutional Court of Hungary, A paper delivered at an International Legal Training Workshop on Effective Case Management, Effective Decision Understanding the ECHR at Sarajevo between 12 and 13 February 2004.

${ }^{22} 1995$ (3) SA 391 (CC).

23 (2007) CHR 218-235.

${ }^{24}$ See Article 1 of CEDAW above note 2.

${ }^{25}$ UN Division for the Advancement of Women: Reservations to CEDAW available at http:// www.un.org/womenwatch/daw/cedaw/reservations.htm (accessed 10 August 2012).

${ }^{26}$ African Women's Protocol, above note 3 , Article 1.

${ }^{27}$ See Article 2 of the Women's Protocol above note 3, which drew its inspiration from Article 2 of CEDAW.

${ }^{28}$ See for instance, CEDAW Concluding Observations to the Combined Third, Fourth, and Fifth Periodic Reports of Paraguay, CEDAW/C/PAR/CC/3-5 (15 February 2005) para 23.

29 Ibid.

${ }^{30}$ Human Rights Committee, General Comment 18, Non-discrimination (37th session, 1989), Compilation of General Comments and General Recommendations Adopted by Human Rights Treaty Bodies, U.N. Doc. HRI/GEN/1/Rev.1 at 26 (1994).

${ }^{31}$ HRC General Comment 28 "Equality of Rights Between Men and Women"' (Article 3), UN Doc CCPR/C/21/Revl/Add 10 (2000).

${ }^{32}$ Ibid., para 24.

${ }^{33}$ Comm. No. 211/98 2011) AHLR.84.

${ }_{35}^{34}$ Mojekwu v Iwachukwu [2004] 4 SC (Part II) 1.

35 [1997] 7 N.W.L.R. 283.

${ }^{36}$ This is a notorious custom among the Igbos of the south eastern part of Nigeria, which denies right of inheritance to a female child. It should be noted however, that this practice is not limited to the Igbo people but is commonly observed across Africa.

${ }^{37}$ Unreported suit no CA/E/2006 (delivered on 24 January 2008).

${ }^{38}$ See for instance, Malpractices Against Widows and Widowers (Prohibition) Law 2005 in Ekiti, Enugu, Imo, Ebonyi, and Anambra states; see also Inhuman Treatment of Widows (Prohibition) Law 2004 of Edo state.

${ }^{39}$ Nigeria CEDAW NGO Coalition Shadow Report above note 4.

${ }^{40}$ See for instance, CEDAW Committee General Recommendation 21 on Equality in Marriage and Family Relations and General Recommendation 24 on Women and Health UN GAOR, 1999, Doc A/54/38 Rev 1. 
${ }^{41}$ General Recommendation 21 paras 34 and 35.

42 CEDAW Committee, General Recommendation 27 on older Women and Protection of their human rights CEDAW/C/2010/47/GC.1 para 53.

43 CEDAW Committee, General Recommendation 28 on the Core Obligations of States Parties under Article 2 of CEDAW CEDAW/C/2010/47/GC.2 para 31.

${ }^{44}$ Concluding Observations of the CEDAW Committee: Nigeria 41st Session 30 June-18 July 2008 CEDAW/C.NGA/CO/6 para 20.

${ }^{45}$ Committee on the Rights of the Child: Consideration of Reports submitted by States Parties under Article 44 of the Convention. Second Periodic Reports of States Parties: Nigeria CRC/C/ $70 /$ Add. 24 para 43.

46 Committee on CRC Concluding Observation on Nigeria 2005 CRC/C/146 adopted at the 1025th meeting held on 28th of January 2005 paras 56 and 57.

47 Ibid.

${ }^{48}$ HRC above note 30 .

\section{REFERENCES}

Armstrong, A., Beyani, C., Himonga, C. et al (1993). 'Uncovering reality: excavating women's rights in African family laws', International Journal of Law and the Family 7, 314-69.

Ba, M. (1981). So Long a Letter, Dakar: Heinemann.

Banda, F. (2006). 'Blazing a trail: the African protocol on women's human rights comes into force', Journal of African Law 50, 72-84.

Bond, J. (2010). 'Gender discourse and customary law in Africa', Southern California Law Review 83, 510-70.

Chirwa, D. M. (2006). 'Reclaiming (Wo)manity: the merits and demerits of the African protocol on women's rights', Netherlands International Law Review 53, 63-95.

Cobbah, J. A. M. (1987). 'African values and the human rights debate: an African perspective', Human Rights Quarterly 9, 309-31.

Centre on Housing Rights and Evictions (COHRE). (2002). Violence: The Impact of Forced Evictions on Women in Palestine, India and Nigeria, Geneva: COHRE.

Cook, R. J., Dickens, B. M. and Fathalla, M. F. (2003). Reproductive Health and Human Rights: Integrating Medicine, Ethics, and Law, Oxford: Oxford University Press.

Donnelly, J. (1984) . 'Cultural Relativism and Universal Human Rights', Human Rights Quarterly 6, 400-19.

Donnelly, J. (2003). Human Rights in Theory and Practice, Ithaca: Cornell University Press.

Eboh, M. P. (1998). 'The woman question: African and western perspectives' in E. C. Eze (ed), African Philosophy: An Anthology, London: Blackwell Publishers, 333-37.

Ewelukwa, U. (2002). 'Pre-colonialism, gender, customary injustices: widows in African societies', Human Rights Quarterly 24, 425-84.

Federal Ministry of Women Affairs. (2006). National Gender Policy, Abuja: Federal Ministry of Women Affairs.

Gunning, I. (1992). 'Arrogant perception, world traveling and multicultural feminism: The case of female genital surgeries', Columbia Human Rights Law Review 23, 189-248.

Iwobi, A. U. (2008). 'No cause for merriment: the position of widows under Nigerian law', Canadian Journal of Women and Law 20, 37-86.

Lewis, H. (1995). 'Between "Irua" and "female genital mutilation": feminist human rights discourse and the cultural divide', Harvard Human Rights Journal 21, 1-55.

Mama, A. (1997). 'Heroes and villains: conceptualising colonial and contemporary violence against women in Africa', in M. Alexander et al (ed), Feminist Genealogies, Colonial Legacies, Democratic Futures, New York and London: Routledge, 46-62.

Margalit, A. (2003). The Ethics of Memory, Cambridge Mass: Harvard University Press.

Mukasa, R. (2008). The African Women's Protocol: A New Dimension for Women's Rights in Africa, South Africa: Fanele.

National Population Commission (NPC). (2006). National Census, Abuja: NPC.

Nyanzi, S., Emodu-Walakari, M. and Serwaniko, W. (2009). 'The widow, the will, and widowinheritance in Kampala: revisiting victimization arguments', Canadian Journal of African Studies 43, 12-33. 
Obiora, L. A. (1997). 'Feminism, globalisation and culture: after Beijing', Indiana Journal of Global Legal Studies 4, 355-406.

Oyeniyi, A. and Ayodeji, I. (2010). 'Widowhood practices among the Yorubas of south west Nigeria: are there differences in what women experience due to their status?', Gender and Behaviour 8, 3152-67.

Samuel, G. C. E. (2011). 'Emergent issues on widowhood practices in Igbo culture: between the video screen and reality', Unizik Journal of Arts and Humanities (UJAH) 8, 184-93.

Sossou, M. A. (2002). 'Widowhood practices in West Africa: the silent victims', International Journal of Social Welfare 11, 201-09.

Ssenyonjo, M. (2007). 'Culture and human rights of women in Africa: between light and shadow', Journal of African Law 51, 39-67.

Tamale, S. (2004). 'Gender trauma in Africa: enhancing women's links to resources', Journal of African Law 48, 50-61.

Tamale, S. (2008). 'The right to culture and the culture of rights: a critical perspective on women's sexual rights in Africa', Feminist Legal Studies 16, 47-69.

Terry, G. (2007). Women's Rights, London: Palgrave Macmillan.

Williams, S. (2004). 'Nigeria, its women and international law: beyond rhetoric', Human Rights Law Review 4, 229-55. 